\title{
EVALUATING PRESCRIBED FIRE EFFECTIVENESS USING Permanent Monitoring Plot Data: A CASE Study
}

\author{
Kristen M. Waring ${ }^{1 *}$, Kristen J. Hansen ${ }^{1,2,3}$, and William T. Flatley ${ }^{1}$ \\ ${ }^{1}$ Northern Arizona University, School of Forestry, \\ 200 E. Pine Knoll Drive, Flagstaff, Arizona 86011, USA \\ ${ }^{2}$ US Department of Interior, National Park Service, Zion National Park, \\ 1 State Route 9, Springdale, Utah 84767, USA \\ ${ }^{3}$ Current address: US Department of Interior, National Park Service, \\ Lassen Volcanic National Park, \\ 38050 Highway 36 E, Mineral, California 96063, USA \\ *Corresponding author: Tel.: +1-928-523-4920; e-mail: Kristen.waring@nau.edu
}

RESUMEN

\begin{abstract}
Since Euro-American settlement, ponderosa pine forests throughout the western United States have shifted from high fire frequency and open canopy savanna forests to infrequent fire and dense, closed canopy forests. Managers at Zion National Park, USA, reintroduced fire to counteract these changes and decrease the potential for high-severity fires. We analyzed existing permanent monitoring plot data collected between 1995 and 2010 to assess achievement of management objectives related to prescribed fire in ponderosa pine forests. Following first entry fire, ponderosa pine (Pinus ponderosa C. Lawson var. scopulorum Engelm.) and Gambel oak (Quercus gambelii Nutt.) overstory and midstory densities declined between 10\% and $45 \%$ and effectively shifted the Gambel oak diameter distribution toward larger trees. Second entry fires had a greater effect, reducing ponderosa pine and Gambel oak overstory and midstory densities between $24 \%$ and
\end{abstract}

Desde la colonización euro-americana, los bosques de pino ponderosa en todo el oeste de Estados Unidos han cambiado de ser bosques con fuegos altamente frecuentes, con canopias abiertas tipo sabana, a bosques con fuegos infrecuentes cuya canopia es cerrada y densa. Los administradores del Parque Nacional Zion, EEUU, reintrodujeron el fuego para contrarrestar estos cambios y disminuir el potencial de fuegos muy severos. Nosotros analizamos datos existentes de parcelas permanentes de monitoreo tomados entre 1995 y 2010 para determinar el logro de objetivos de manejo relacionados a quemas prescriptas en bosques de pino ponderosa. A continuación de la primera tanda de quemas, las densidades de los estratos superior y medio del pino ponderosa (Pinus ponderosa C. Lawson var. scopulorum Engelm.) y el Gambel oak (Quercus gambelii Nutt.) declinaron entre el $10 \%$ y $45 \%$, y modificaron efectivamente la distribución del diámetro del Gambel oak hacia árboles más grandes. La segunda tanda de quemas tuvieron un efecto mayor, reduciendo las densidades de los estratos superior y medio de pino ponderosa y Gambel oak entre un $24 \%$ y $92 \%$. La distribución de los diáme- 
$92 \%$. Diameter distributions of both species shifted toward fewer, larger trees following second entry fires. Total fuel load was reduced by $<20 \%$ in first entry fires and by half in second entry fires. Several objectives identified by the National Park Service (e.g., overstory ponderosa pine reduction) were not achieved with either fire entry; however, power analysis indicated that sample sizes were not adequate to fully detect long term changes following first entry fires. First entry, low intensity prescribed fire alone may not meet management objectives in southwestern ponderosa pine forests. We recommend using multiple fire entries or increased fire intensity if mechanical treatments are not also being utilized concurrently. Long term fire effects data is critical to adaptive management in national parks; however, the utility of this data could be improved through increased sample sizes, consistent data archiving, and regional scale analyses. tros de ambas especies se desplazó hacia unos pocos árboles grandes luego de la segunda tanda de quemas. La carga total de combustible se redujo en $<20 \%$ en la primera tanda de quemas y a la mitad en la segunda tanda de quemas. Varios objetivos identificados por el Servicio del Parque Nacionales (por ej., reducción del estrato superior del pino ponderosa), no se lograron con ninguna quema. Sin embargo, los análisis indicaron que los tamaños de muestras no fueron adecuados para detectar en forma completa cambios de largo plazo después de la primera tanda de quemas. Una sola tanda de quemas prescriptas de baja intensidad pueden no cumplir con los objetivos de manejo en los bosques de pino ponderosa del sudoeste. Nosotros recomendamos utilizar varias tandas de quemas prescriptas o fuegos más intensos si los tratamientos mecánicos no están siendo utilizados concurrentemente. Los datos de los efectos del fuego a largo plazo son críticos para el manejo adaptativo en los parques nacionales; sin embargo, la utilidad de estos datos podría ser mejorada a través del incremento de los tamaños de muestra, de archivos de datos consistentes, y de análisis a escala regional.

Keywords: fuel treatments, fire management, fire monitoring, Gambel oak, ponderosa pine, restoration, southwest USA, Zion National Park

Citation: Waring, K.M., K.J. Hansen, and W.T. Flatley. 2016. Evaluating prescribed fire effectiveness using permanent monitoring plot data: a case study. Fire Ecology 12(3): 2-25. doi: 10.4996/fireecology.1203002

\section{INTRODUCTION}

Prior to Euro-American settlement, ponderosa pine (Pinus ponderosa C. Lawson var. scopulorum Engelm.) communities in the American Southwest grew primarily in open, park-like savannas, maintained by low intensity, frequent fire (Cooper 1960, Barrett et al. 1980, Madany 1981, Harrington and Sackett 1992). Beginning in the latter half of the 1800 s, cattle and sheep grazing, timber harvesting, and fire exclusion and suppression ac- tivities led to increases in tree and woody shrub density, decreases in understory herbaceous cover, and shifts in understory species composition, culminating with an increase in potential fire severity (Covington and Moore 1994, Allen et al. 2002, Fulé et al. 2004). Shifts occurred from open pine savannas with lush understory grasses to closed canopy pine forests with the understory dominated by unpalatable woody shrub species (Madany 1981). Dense ponderosa pine forests are not only more susceptible to high severity fire, but 
have higher rates of inter-tree competition, which may contribute to climate related mortality, particularly as the Southwest becomes warmer and drier in the future (Allen et al. 2010, Williams et al. 2012)

Prescribed fire is a logical management option for restoring forest structure and fuel loading to more resilient conditions (Ryan et al. 2013), especially when mechanical tree removal operations are not as feasible (e.g., national parks or wilderness areas). However, in recent years, numerous studies have found that low severity first entry prescribed fires are not effective in meeting objectives related to tree density and fuel load reductions (Fulé et al. 2012 and references within, Higgins et al. 2015). Conversely, fire of higher intensity may be effective in restoring natural fire behavior in ponderosa pine forests (Fulé et al. 2012). While mechanical treatments prior to prescribed burning are more effective (Harrington and Sackett 1990, Arno et al. 1995, Covington et al. 1997), mechanical treatments may not be allowed in protected areas, leaving prescribed fire as the tool of choice. This poses a management challenge as prescribed burning alone may not completely meet management objectives (Arno et al. 1995, Ryan et al. 2013).

We use a case study of the prescribed burning and fire effects monitoring program at Zion National Park (Zion), Utah, USA, to explore whether fire managers are meeting management objectives through the use of prescribed fire. Because Zion is almost $90 \%$ designated wilderness, managers have limited ability to utilize tools other than prescribed fire in managing vegetation. The Zion Fire Monitoring Plan, which is imbedded within the Fire Management Plan (USDI NPS 2005), contains broad objectives for each vegetation type that receives prescribed fire treatments. Objectives for the ponderosa pine type include the reduction of ponderosa pine density and fuel loading. In particular, densities of ponderosa pine between $10.2 \mathrm{~cm}$ to $30.5 \mathrm{~cm}$ diameter at breast height (dbh) would be reduced by $30 \%$ to $60 \%$, fuel loading would be reduced by $40 \%$ to $60 \%$ (litter and duff) or $40 \%$ to $80 \%$ (1000 $\mathrm{hr}$ time lag fuels), and large ponderosa pine trees $(>61.0 \mathrm{~cm} \mathrm{dbh})$ would be retained with $<20 \%$ post-fire mortality. A corresponding increase in crown spacing would occur, reducing canopy cover and creating more open forest conditions (USDI NPS 2005). Objectives are considered met if the desired condition is met within a $20 \%$ error allowance.

\section{Objectives}

At Zion and elsewhere, fire managers do not have a complete understanding of how well prescribed fire objectives are being met through prescribed fire programs. The overarching goal of this project, therefore, was to use permanent monitoring plot data to determine whether Zion was meeting its prescribed fire management objectives in the ponderosa pine forest and how many monitoring plots are necessary to detect post-fire differences. Ponderosa pine forests in Zion are dominated by ponderosa pine but Gambel oak (Quercus gambelii Nutt.) is a frequent understory component. We focused on long term (10 yr) effects of first entry prescribed fire and short term (2 yr) effects of second entry prescribed fire (Figure 1). We hypothesized that both the first and second entry fires would result in reductions in ponderosa pine densities and fuel loading through time; however, we predicted that a second entry fire would provide more significant changes over a shorter time period. We further hypothesized that reductions would also be found in Gambel oak densities but that increases in understory herbaceous vegetation would occur following fire. Finally, we hypothesized that conditions following both fire entries would be suitable for ponderosa pine regeneration. 

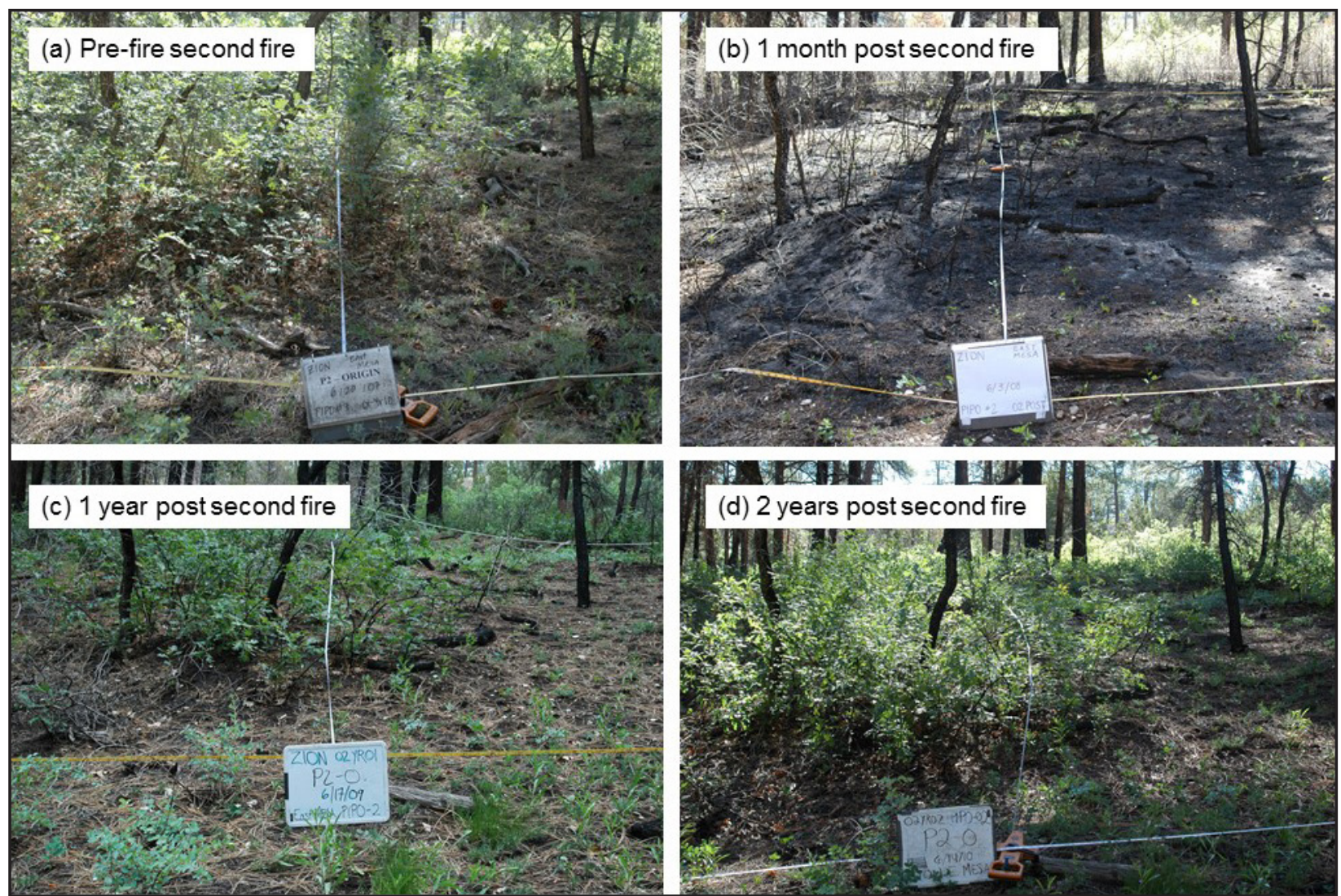

Figure 1. Successive photos of ponderosa pine fire effects on plot \#2 in Zion National Park, Utah, USA. The plot was "scorched" (see Table 1 for explanation of fire monitoring handbook burn severity definitions) in an initial prescribed fire in 1997. The plot was "lightly burned" in a second prescribed fire that occurred in 2008. Photos were taken (a) prior to the second prescribed fire, (b) 1 month after the second fire, (c) 1 year after the second fire, and (d) 2 years after the second fire. All photos were collected at approximately the same location.

\section{METHODS}

\section{Study Area}

Zion is located in southwestern Utah at the eastern edge of the Great Basin and northwestern edge of the Southwest, $55 \mathrm{~km}$ northeast of St. George, Utah, USA ( $37^{\circ} 17^{\prime} 24^{\prime \prime} \mathrm{N}, 113^{\circ} 2^{\prime}$ $\left.56^{\prime \prime} \mathrm{W}\right)$. The topography of Zion consists of deeply incised canyons with relatively flat plateaus. The ponderosa pine forests are found on these flat plateaus. The first fire management plan for Zion was initiated in 1985 . The plan stated that prescribed natural fire, defined as a lightning ignited fire burning within prescribed conditions, would be allowed to influ- ence the existing fire adapted ecosystems within the park boundary unless the fire impacted public or visitor safety, structures, or private lands. Furthermore, the plan recommended the initiation of intentional burning on the plateaus to maintain or re-establish fire adapted communities and to re-introduce fire as an "agent of change" in the ecosystem (USDI NPS 1985). These goals aligned with the Leopold Report (Leopold et al. 1963), which recommended that a primary goal of the National Park Service (NPS) should be the maintenance or re-creation, as necessary, of the biotic communities within each park to the condition that was present prior to Euro-American settlement. Managers within the NPS are required 
to monitor short term and long term vegetation changes for all wildland fires (USDI NPS 1991, 2008a, 2008b). Fire and resource managers implemented the first prescribed fire within the Zion boundary within the ponderosa pine type in 1992 (US Department of the Interior National Park Service 1995 unpublished memo, on file at Zion National Park, Springdale, Utah, USA). Subsequently, the Fire Effects Monitoring Program at Zion was formally established in 1995 and still exists today. Fire managers delineated prescribed fire burn units within fire-adapted ecosystems affected by fire exclusion in Zion, including the ponderosa pine type. Burn units were then treated with prescribed fire to replicate the natural disturbance regime; fire monitoring plots within each unit were considered burned at that time even if the spatial pattern of the fire precluded a plot from actual burning. Personnel implemented prescribed fire treatments from March through June and from August through November, depending upon weather prescription elements described in the individual prescribed fire burn plan and vegetation type description sheet. While individual prescribed fire reports were not available for each fire included here, an example of burn unit size and weather conditions for a fall burn and a spring burn are included in Appendix A.

This study was conducted in the ponderosa pine type within Zion. The prevalent soil type found in the study sites was loamy phases of the Kolob and Detra Series derived from the Carmel limestone (Mortensen et al. 1977). Average elevation of the ponderosa pine type was 1970 m with an average annual precipitation of $456 \mathrm{~mm} \mathrm{yr}^{-1}$, occurring primarily in winter as snowfall (Harper 1993). Between 1995 and 2009, Zion personnel utilized standard NPS Fire Monitoring Handbook (FMH) protocols to install 77 fire monitoring plots, randomly located within designated monitoring types (USDI NPS 2003). Of these plots, 18 were in the ponderosa pine type. We analyzed data from 15 of the 18 plots that met our criteria for inclusion (plots that encompassed a full range of pre-burn through 10-year (first entry) or 2-year (second entry) remeasurements; Table 1). Time between first and second entry fires ranged from $2 \mathrm{yr}$ to $11 \mathrm{yr}$, with a mean of $8.9 \mathrm{yr}$ between fires (Table 1). The 15 plots were established across a total of 11 prescribed fire treatments that included both spring and fall burns. Prescribed fire vegetation and substrate burn severity, which ranges from 1 (heavily burned) to 5 (unburned) (USDI NPS 2003, see Table 1 for detailed descriptions of the burn severity categories found on plots used in this study), averaged 3.9 for first entry and 3.7 for second entry fires (Figure 1).

\section{Field Methods}

Field crews re-measured each plot on a pre-defined schedule set by the FMH: pre fire; immediately post fire; and $1 \mathrm{yr}, 2 \mathrm{yr}, 5 \mathrm{yr}, 10$ $\mathrm{yr}$, and $20 \mathrm{yr}$ post fire or until re-treatment occurred (USDI NPS 1991, 2003). Data available for this project only included up to $10 \mathrm{yr}$ post fire (Table 1). Ponderosa pine forest FMH plots were $20 \mathrm{~m} \times 50 \mathrm{~m}(0.1 \mathrm{ha})$ and protocols are detailed in the FMH (USDI NPS 1991, 2003). Relevant measurements for this research included live overstory, midstory, and understory vegetation (woody and nonwoody); forest floor cover assessments; fire severity assessment; and downed and dead woody debris (fuel loading). Trees were included as overstory if they were $>15.1 \mathrm{~cm} \mathrm{dbh}$, as midstory (defined in FMH as poles) if dbh was $2.51 \mathrm{~cm}$ to $15.0 \mathrm{~cm}$, and as understory seedlings if they were less than $2.5 \mathrm{~cm}$ dbh. Seedlings were further classified into the following height classes: $\leq 0.15 \mathrm{~m}, 0.16 \mathrm{~m}$ to 0.30 $\mathrm{m}, 0.31 \mathrm{~m}$ to $0.60 \mathrm{~m}, 0.61 \mathrm{~m}$ to $1.0 \mathrm{~m}, 1.0 \mathrm{~m}$ to $2.0 \mathrm{~m}$, and $>2.0 \mathrm{~m}$. In addition to $\mathrm{dbh}$, crown position (dominant, co-dominant, intermediate, suppressed, or open grown; Smith et al. 1997) and damage (abiotic and biotic, including stem form issues; USDI NPS 2003) was recorded for all overstory and midstory trees. Live woody and herbaceous understory plant 
Table 1. Ponderosa pine fire effects monitoring plots located at Zion National Park, Utah, USA, by fire entry years, burn severity, season of burn, and whether the plot was included in analysis of first entry fires, second entry fires, or both. Plots, listed by field number, used for first entry fire data analysis included those with $1 \mathrm{yr}, 2 \mathrm{yr}, 5 \mathrm{yr}$ and $10 \mathrm{yr}$ post-fire remeasurements, and those used for second entry fire data analysis included those with $1 \mathrm{yr}$ and $2 \mathrm{yr}$ post-fire remeasurements. Burn severity by category is as defined in USDI NPS (2003). Pre-fire data were collected for all plots.

\begin{tabular}{|c|c|c|c|c|c|c|c|c|}
\hline \multicolumn{3}{|c|}{ Prescribed fire year } & \multicolumn{2}{|c|}{ Burn severity } & \multicolumn{2}{|c|}{ Season of burn } & \multicolumn{2}{|c|}{ Included in analysis } \\
\hline Plot & $\begin{array}{l}\text { First } \\
\text { entry }\end{array}$ & $\begin{array}{c}\text { Second } \\
\text { entry }\end{array}$ & First entry ${ }^{a}$ & Second entry & First entry & $\begin{array}{c}\text { Second } \\
\text { entry }\end{array}$ & $\begin{array}{l}\text { First } \\
\text { entry }\end{array}$ & $\begin{array}{c}\text { Second } \\
\text { entry }\end{array}$ \\
\hline 3 & 1995 & 2006 & Scorched & Scorched & Late summer & Spring & $\mathrm{X}$ & $\mathrm{X}$ \\
\hline 6 & 1995 & 1997 & Lightly burned & Unburned & Late summer & Spring & & $\mathrm{X}$ \\
\hline 7 & 1996 & 2004 & Unburned & Lightly burned & Fall & Fall & & $\mathrm{X}$ \\
\hline 8 & 1996 & 2004 & Scorched & Lightly burned & Fall & Fall & & $\mathrm{X}$ \\
\hline 10 & 1996 & 2004 & Scorched & Scorched & Fall & Fall & & $\mathrm{X}$ \\
\hline 1 & 1997 & & Scorched & & Spring & & $X$ & \\
\hline 2 & 1997 & 2008 & Scorched & Lightly burned & Spring & Spring & $X$ & $\mathrm{X}$ \\
\hline 4 & 1997 & 2008 & Lightly burned & Unburned & Spring & Spring & $X$ & $X$ \\
\hline 5 & 1997 & 2006 & Scorched & Unburned & Spring & Spring & & $\mathrm{X}$ \\
\hline 17 & 1997 & 2008 & Lightly burned & Scorched & Fall & Fall & $X$ & $X$ \\
\hline 26 & 1997 & 2007 & Scorched & Lightly burned & Fall & Fall & & $X$ \\
\hline 12 & 1998 & & Unburned & & Fall & & $X$ & \\
\hline 13 & 1998 & & Scorched & & Fall & & $\mathrm{X}$ & \\
\hline 14 & 1999 & & Scorched & & Fall & & $\mathrm{X}$ & \\
\hline 47 & 1999 & 2007 & Scorched & Scorched & Fall & Fall & & $\mathrm{X}$ \\
\hline & & & & & & Sample si & 8 & 11 \\
\hline
\end{tabular}

${ }^{\text {a }}$ Fire monitoring handbook burn severity categories in order of increasing severity: unburned $<$ scorched $<$ lightly burned. Unburned (5 value) is not burned. Scorched (4 value) includes litter partially blackened, duff nearly unchanged, and wood and leaf structures unchanged. Lightly burned (3 value) includes litter charred to partially consumed, upper duff layer may be charred but is not altered over the entire depth, surface appears black, woody debris is partially burned, logs are scorched or blackened but not charred, and rotten wood is scorched to partially burned.

cover, litter, and bare ground cover were recorded using one $50 \mathrm{~m}$ point intercept transect with a cover measurement recorded every 30 $\mathrm{cm}$. Trees less than $2 \mathrm{~m}$ tall were recorded in the woody understory cover data as well as in the seedling count data (described above). Four standard planar fuel transects were used to inventory dead and down woody material using modified Brown's (1974) protocol. Transects extended for $15.2 \mathrm{~m}$ in random directions away from the center line of each plot, originating at $10 \mathrm{~m}, 20 \mathrm{~m}, 30 \mathrm{~m}$, and $40 \mathrm{~m}$. Fuels were tallied by time lag class along each transect ( $1 \mathrm{hr}$ and $10 \mathrm{hr}: 0 \mathrm{~m}$ to $1.8 \mathrm{~m} ; 100 \mathrm{hr}$ : $0 \mathrm{~m}$ to $3.7 \mathrm{~m}$; $1000 \mathrm{hr}: 0 \mathrm{~m}$ to $15.2 \mathrm{~m}$ ). Litter and duff depth were recorded every $1.5 \mathrm{~m}$ for a total of 10 measurements per transect line. Field crews measured burn severity immedi- ately post fire (approximately 4 weeks post fire) at each duff and litter measurement point (every $1.5 \mathrm{~m}$ ) along the previously established fuel transects. At each point, fire severity was categorized from unburned (5) to heavily burned (1) within a $20 \mathrm{~cm} \times 20 \mathrm{~cm}$ area $(400$ $\mathrm{cm}^{2}$ ) for both substrate and vegetation. The immediate post-fire remeasurement included fuel transects, tree scorch height and percent, and overstory tree char height. All other postfire remeasurements included all variables.

\section{Data Analysis}

Data for the 15 plots were extracted from the software program FFI (FEAT/FIREMON Integrated; Lutes et al. 2009) to allow for further statistical analysis. Within the 15 plots, 
all pre- and post-fire data were available through $10 \mathrm{yr}$ after the first entry fire for 8 plots, and through $2 \mathrm{yr}$ after the second entry fire for 11 plots. Four plots included in first entry analysis that were subsequently burned a second time were therefore also included in the second entry analyses.

We analyzed changes through time for overstory, midstory, and understory trees; live understory cover; and forest floor substrate. Overstory and midstory response variables included ponderosa pine, Gambel oak, and overall tree species density (number ha-1) and basal area $\left(\mathrm{m}^{2} \mathrm{ha}^{-1}\right)$. Live understory cover response variables included forb, graminoid, woody understory (shrubs and small trees), and total vegetation cover, and tree seedling density. Forest floor substrate variables included fuel loading and litter and bare ground cover.

All response variables except litter cover were non-normally distributed and transformations were also non-normal. Consequently, permutation based nonparametric multivariate analysis of variance (PERMANOVA) tests were conducted with PC-ORD version 5 (McCune and Mefford 2006) and calculated with the method of Anderson (2001). All PERMANOVA analyses were performed using Euclidean distances and 4999 randomizations with a randomized seed number selected from time of day. This analysis allowed for comparisons among groups in which non-normality is present in the data and produces a pseudo $F$ statistic (Anderson 2001), which is what we reported here. All response variables were analyzed for a significant difference between treatment years. Pair-wise comparisons were made following significant PERMANOVA results $(P<0.05)$. PC-ORD does not correct the $P$ values for multiple comparisons. We chose not to correct the $P$ values due to the small sample size and to reduce the probability of making a Type II error. Plots were assumed independent in space and time. However, the inference of our data is limited due to violation of this assumption and pseudoreplication in- herent in this and other prescribed fire research (multiple plots in a single fire treated as independent samples). We reported results regardless of significance because results may be ecologically important even if they are not statistically significant; pseudo $F$ and $P$ values are reported to help the reader better understand and interpret the results. We used a power analysis to assess the number of plots needed to detect differences between groups in both first and second entry fires. This analysis was conducted in $\mathrm{R}$ statistical software ( $\mathrm{R}$ Core Development Team 2015).

\section{RESULTS}

\section{Pre-Fire Conditions}

Prior to implementation of prescribed fire, overstory and midstory ponderosa pine densities were 222 trees ha-1 and 80 trees $^{-1} \mathrm{ha}^{-1}$, respectively (Figure 2). Ponderosa pine was the principal overstory species ( $>65 \%$ of stems recorded), with minor components of Gambel oak ( $15 \%$ to $30 \%$ of recorded stems). Gambel oak dominated the midstory with densities at least twice as high as ponderosa pine midstory densities, and also dominated understory live vegetation cover (Figures 3 and 4, Table 2). Other tree species (Juniperus scopulorum Sarg., J. osteosperma [Torr.] Little, Abies concolor [Gord. \& Glend.] Lindl. ex Hildebr., Pseudotsuga menziesii [Mirb.] Franco, and Pinus edulis Engelm.) were present but comprised $<10 \%$ of live stems recorded, primarily representing trees $<5 \mathrm{~cm}$ dbh (data not shown). Perennial graminoid cover was sparse pre fire, with only slightly higher forb cover (Table 2). Bare ground cover was also low, but litter cover was relatively high (Figure 5). Exotic grass species were rare with only $0.03 \%$ of the total cover. Total fuel loading was dominated by litter and duff with minor components of 1000 $\mathrm{hr}$ and fine fuels $(1 \mathrm{hr}, 10 \mathrm{hr}$, and $100 \mathrm{hr}$ time lag fuels) (Figure 6). 


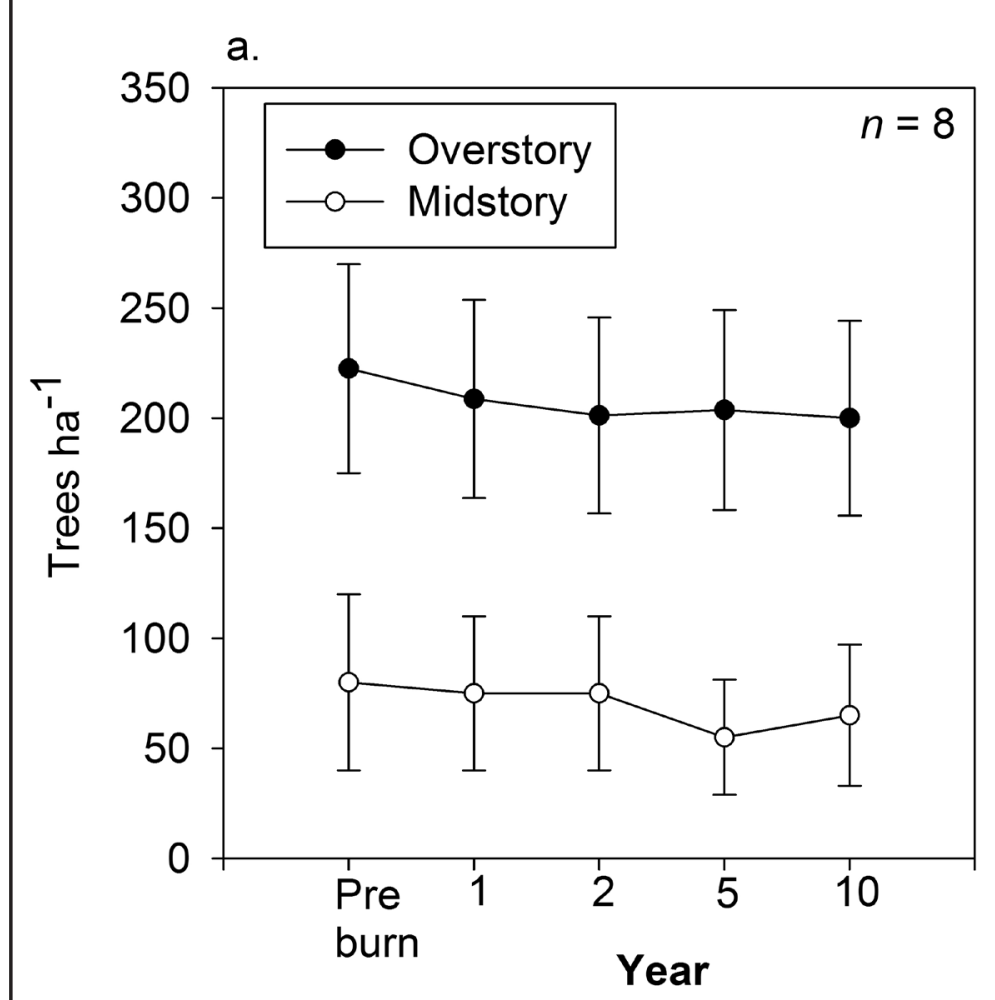

b.

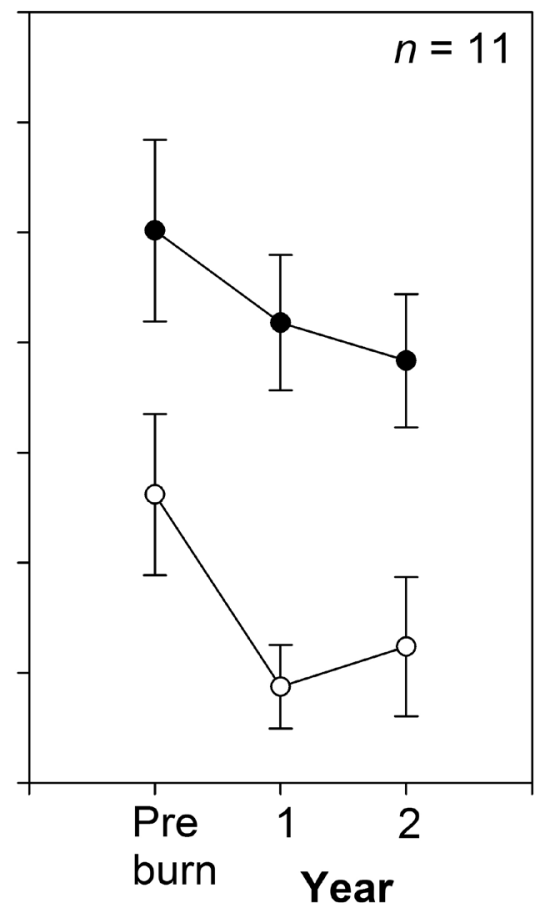

Figure 2. Ponderosa pine overstory and midstory tree density through time for (a) first entry fires and (b) second entry fires. No significant differences were found between treatment years within an entry. Bars and lines represent means and standard errors. Time of plot measurement indicates when measurements occurred: Pre burn = immediately pre fire; numbers indicate years post fire. Data from permanent monitoring plots located at Zion National Park, Utah, USA.

\section{First Entry Fire}

We found few significant differences in the response variables following first entry fires. Overstory ponderosa pine density decreased by $10 \% 1 \mathrm{yr}$ post fire but then remained relatively constant thereafter through year 10 post fire $\left(F_{4,35}=0.071, P=0.989\right.$; Figure 2$)$. Such modest density reductions did not result in a discernible shift in the live tree diameter distribution (Figures 3a and 3c). Basal area did not decrease post fire but increased slightly through year 10 post fire ( $\sim 5 \%$ increase, Table $2)$. In the ponderosa pine midstory, neither density $\left(F_{4,35}=0.087, P=0.988\right)$ nor basal area ( $25 \%$ reduction, $\left.F_{4,35}=0.096, P=0.981\right)$ decreased significantly following the single entry fire (Table 2, Figure 2). Overstory and midstory Gambel oak tree densities decreased $29 \%$ and $45 \%$, respectively, in the first year post fire, although neither reduction was statistically significant (Table 2). By year 10, the Gambel oak midstory had declined by $62 \%$ from pre-fire densities while overstory Gambel oak remained fairly stable through time (28.5\% decrease; Table 2$)$. The decline in tree density corresponded with a shift toward larger diameter live trees and a more unimodal diameter distribution (Figures $3 b$ and $3 d$ ).

Ponderosa pine seedling density was highly variable throughout time since fire (Figures $7 \mathrm{a}$ and $7 \mathrm{c}$ ). The smallest size class, $0.01 \mathrm{~m}$ to $0.15 \mathrm{~m}$ tall, varied between 83 trees $\mathrm{ha}^{-1}$ and 3122 trees $\mathrm{ha}^{-1}$ between pre fire and $10 \mathrm{yr}$ post fire. Ponderosa pine seedling densities were high in year 2 but only $3 \%$ of these trees were 


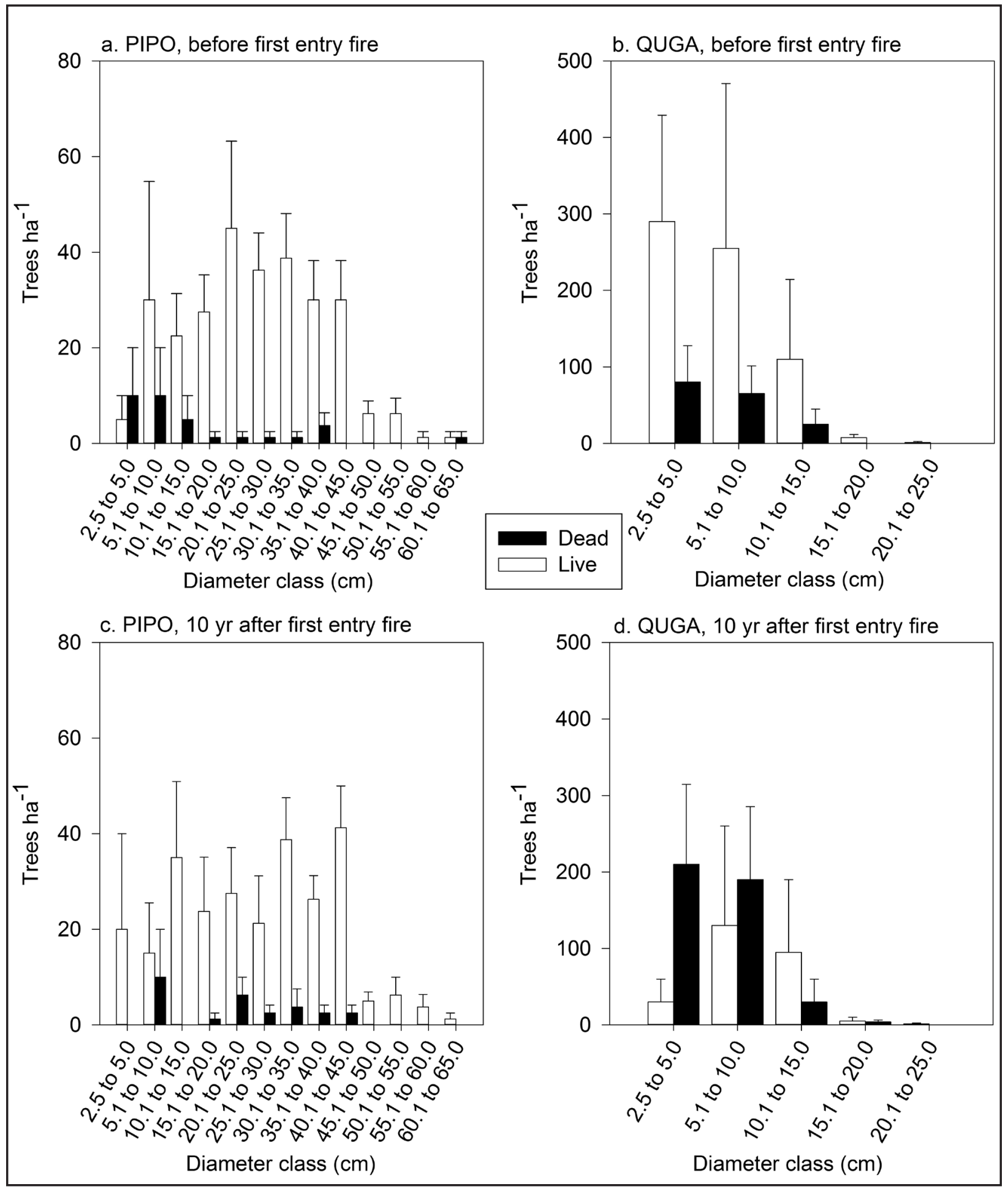

Figure 3. Diameter distributions for live and dead stems of (a) pre first entry fire ponderosa pine, (b) pre first entry fire Gambel oak, (c) $10 \mathrm{yr}$ post-fire ponderosa pine, and (d) $10 \mathrm{yr}$ post-fire Gambel oak. QUGA $=$ Gambel oak, PIPO = ponderosa pine. Distributions based on permanent monitoring plots located at Zion National Park, Utah, USA. $n=8$ plots (first entry) and 11 plots (second entry). 


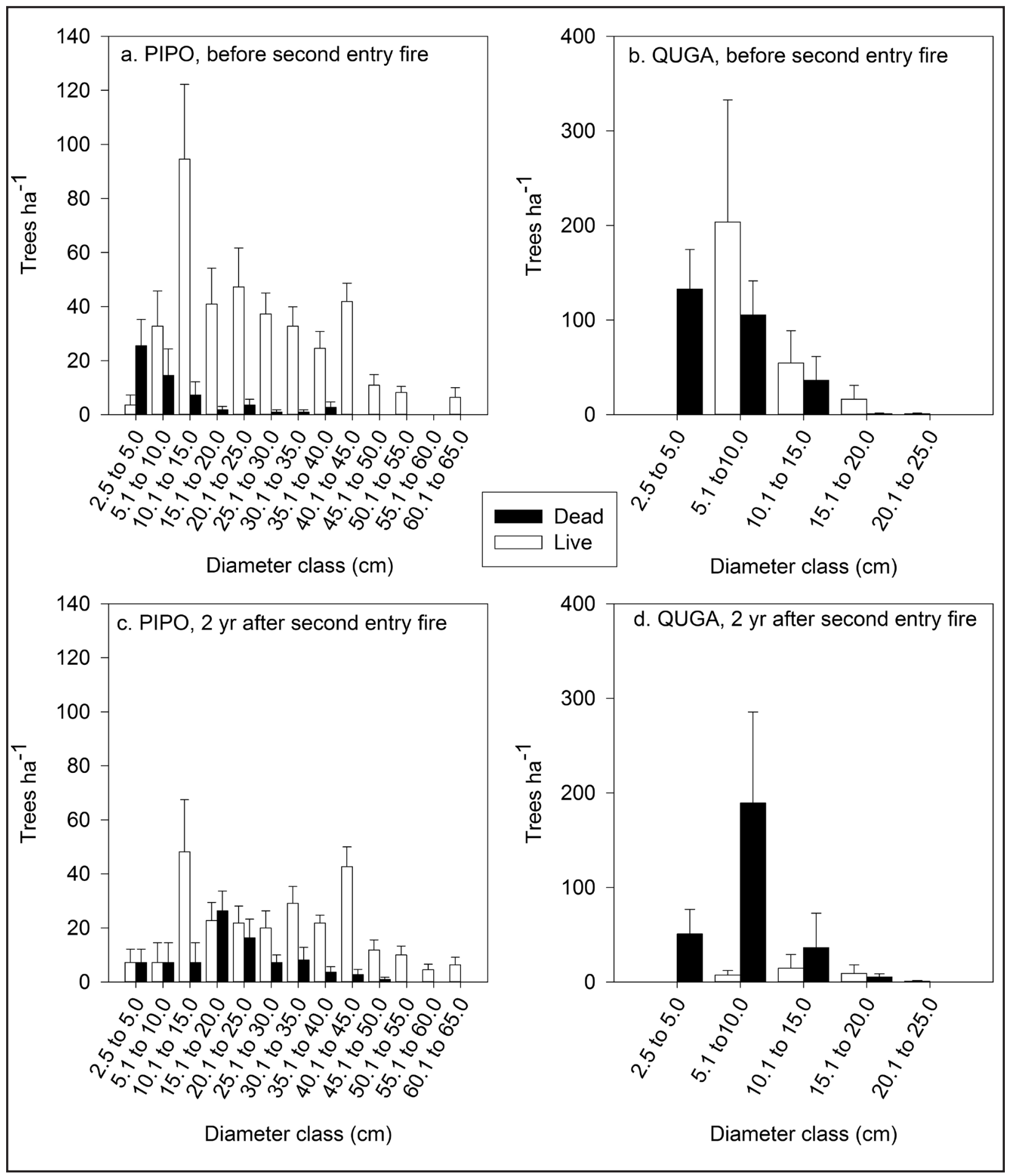

Figure 4. Diameter distributions for live and dead stems of (a) pre second entry fire ponderosa pine, (b) pre second-entry fire Gambel oak, (c) 2 yr post-fire ponderosa pine, and (d) 2 yr post-fire Gambel oak. QUGA $=$ Gambel oak, PIPO = ponderosa pine. Distributions based on permanent monitoring plots located at Zion National Park, Utah, USA. $n=8$ plots (first entry) and $n=11$ plots (second entry). 
Table 2. Mean (standard error) understory and overstory attributes within ponderosa pine prescribed fire burn units by time since burned for a first entry fire. All percentages represent percent cover measurements. Letters represent significant differences $(\alpha \leq 0.05)$ between treatment years using PERMANOVA; $n=8$ plots. QUGA $=$ Gambel oak, PIPO = ponderosa pine. Data from permanent monitoring plots located at Zion National Park, Utah, USA.

\begin{tabular}{lccccc}
\hline & \multirow{2}{*}{ Pre fire } & \multicolumn{4}{c}{ Post-fire years since fire } \\
\cline { 3 - 6 } & & $\mathbf{1}$ & $\mathbf{2}$ & $\mathbf{5}$ & $\mathbf{1 0}$ \\
\hline Understory cover (\%) & & & & \\
Woody shrubs & $14.2(2.7)^{\mathrm{a}}$ & $7.3(1.8)^{\mathrm{b}}$ & $6.9(1.7)^{\mathrm{b}}$ & $5.6(1.0)^{\mathrm{b}}$ & $7.5(2.2)^{\mathrm{ab}}$ \\
QUGA & $22.4(4.1)$ & $8.6(2.9)$ & $19.9(3.4)$ & $19.4(3.4)$ & $27.0(4.4)$ \\
Forb & $9.6(2.8)$ & $8.2(1.9)$ & $12.6(3.1)$ & $5.9(5.0)$ & $7.1(2.3)$ \\
Perennial graminoids & $6.4(3.1)$ & $5.1(2.3)$ & $8.1(3.7)$ & $7.5(4.1)$ & $5.6(2.6)$ \\
$\quad$ Total vegetation & $55.0(8.4)$ & $32.1(5.7)$ & $48.7(6.0)$ & $38.9(6.8)$ & $48.0(3.6)$ \\
\hline & & & & \\
Overstory and midstory & & & & \\
PIPO overstory basal area $\left(\mathrm{m}^{2} \mathrm{ha}^{-1}\right)$ & $20.0(3.8)$ & $20.0(3.6)$ & $20.1(3.6)$ & $21.1(3.7)$ & $21.1(3.7)$ \\
PIPO midstory basal area $\left(\mathrm{m}^{2} \mathrm{ha}^{-1}\right)$ & $0.8(0.4)$ & $0.8(0.3)$ & $0.8(0.3)$ & $0.5(0.2)$ & $0.6(0.3)$ \\
QUGA overstory density $\left(\right.$ trees ha $\left.^{-1}\right)$ & $8.8(5.2)$ & $5.0(5.0)$ & $6.3(6.3)$ & $6.3(6.3)$ & $6.3(6.3)$ \\
QUGA midstory density $\left(\right.$ trees ha $\left.^{-1}\right)$ & $655(447.7)$ & $360(320.8)$ & $345(305.8)$ & $335(306.9)$ & $250(250)$ \\
\hline
\end{tabular}

recorded in the next height class $(0.15 \mathrm{~m}$ to $0.30 \mathrm{~m}$ ) by year 5 , nor were they maintained in the smallest height class (Figure 7). Variability through time was also present in other height classes (up to $1 \mathrm{~m}$ ), with no seedlings over $0.15 \mathrm{~m}$ found either $1 \mathrm{yr}$ or $2 \mathrm{yr}$ post fire. By year 10 post fire, there were 42 trees ha ${ }^{-1}$ in the $0.16 \mathrm{~m}$ to $0.30 \mathrm{~m}$ height class (Figure 7c).

Only woody shrub cover (not including Gambel oak cover) decreased significantly following first entry fire $\left(F_{4.35}=2.964, P=0.030\right.$; Table 2), declining 49\% 1 yr post fire and continuing to decrease in cover until $5 \mathrm{yr}$ post fire, when it increased by $7.5 \%$ between year 5 and year 10 post fire. Gambel oak cover decreased 1 yr post fire from $22 \%$ to $8.5 \%$ cover. Cover then increased in the successive years to above pre-fire values (27\%; Table 2). Percent cover for forb species decreased in the first year following fire, then recovered in year 2 with an increase of $24 \%$ over pre-fire values (Table 2 ). Forb cover then decreased between year 2 and year 5 , then remained stable between year 5 and year 10. Perennial graminoid cover was sparse, ranging between $5 \%$ and $10 \%$ in all years (Table 2). Exotic grass species represented less than $1 \%$ of the total graminoid cover in all time periods (data not shown). Total vegetation cover (woody shrub, Gambel oak, forb, and perennial grasses) decreased $42 \%$ from pre fire to $1 \mathrm{yr}$ post fire, primarily driven by decreases in shrub and Gambel oak cover (Table 2). Total cover then varied through time with successive increases and decreases, ending with a $12 \%$ decrease from prefire values at $10 \mathrm{yr}$ post fire (Table 2). Bare ground cover was less than $12 \%$ and litter cover was more than $40 \%$ throughout all time periods (Figure 5). Bare ground cover following the first entry fire initially increased, then declined to approximately pre-fire levels before decreasing to just below pre-fire levels by year 10. Litter cover showed an increasing trend $1 \mathrm{yr}$ post fire, then varied through time, reaching a $20 \%$ cover increase in year 10 (Figure 5).

Total fuel load showed a decreasing trend through time until the 10-year measurement. Litter and duff represented $87 \%$ of forest floor fuel loading until year 10 post fire, when fine and heavy fuels increased to account for over $33 \%$ of fuel load (Figure 6). Litter and duff fuel loading was reduced by $46 \%$ between pre fire and year 5 post fire, but then increased be- 


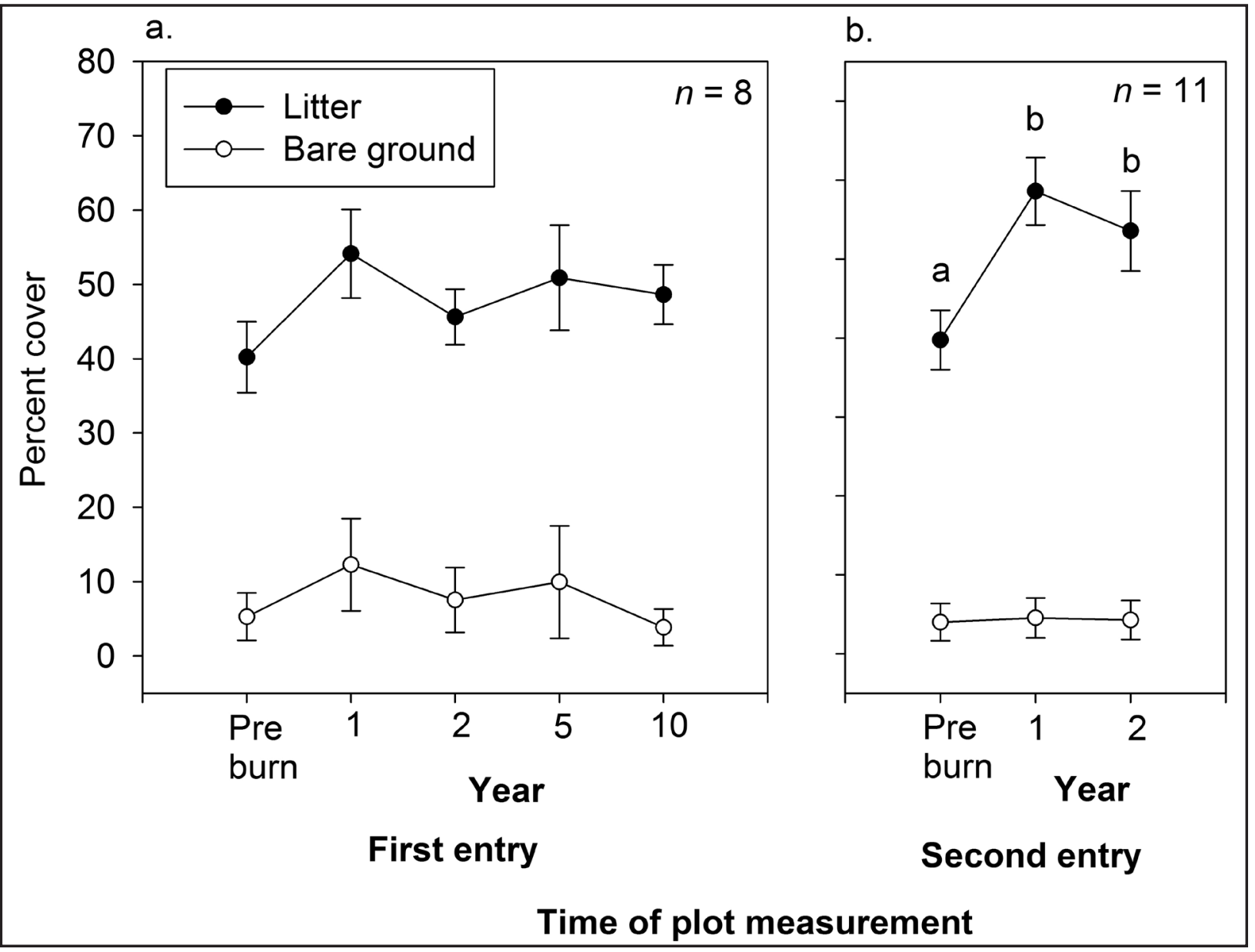

Figure 5. Percent cover of litter and bare ground through time for (a) first entry fires and (b) second entry fires. Different letters indicate significant differences between treatment years $(\alpha \leq 0.05)$. Bars and lines represent means and standard errors. Time of plot measurement indicates when measurements occurred: Pre burn = immediately pre fire; numbers indicate years post fire. Data from permanent monitoring plots located at Zion National Park, Utah, USA.

tween year 5 and year 10, resulting in an overall decrease of only $18 \%$ between pre fire and year 10 post fire (Figure 6).

Power analysis indicated that, to detect significant differences in trees ha-1 with $95 \%$ confidence in first entry fires between all years (pre fire and $1 \mathrm{yr}, 2 \mathrm{yr}, 5 \mathrm{yr}$, and $10 \mathrm{yr}$ post fire), 43 plots would be needed (effect size = 0.238 trees $\left.\mathrm{ha}^{-1}\right)$. Using identified Zion management objectives and confidence intervals of being $80 \%$ confident of detecting significant differences in trees ha ${ }^{-1}$ would still require 27 plots (effect size $=0.238$ trees $\mathrm{ha}^{-1}$ ). These sample sizes are much higher than the $n=8$ we had available to conduct this research.

\section{Second Entry Fire}

Second entry fires had a greater effect on vegetation and fuels than first entry fires. Ponderosa pine and Gambel oak overstory and midstory densities both decreased. By year 2 post fire, overstory ponderosa pine had decreased by $24 \%$ while Gambel oak had decreased by $41 \%$ (Figures 1 and 2, Table 3); however, these were not statistically significant changes. Ponderosa pine midstory density decreased but less so than that of Gambel oak midstory, which significantly declined by $92 \%$ in the first year following the second entry fire $\left(F_{2,30}=3030, P=0.026\right.$; Table 2$)$. The 


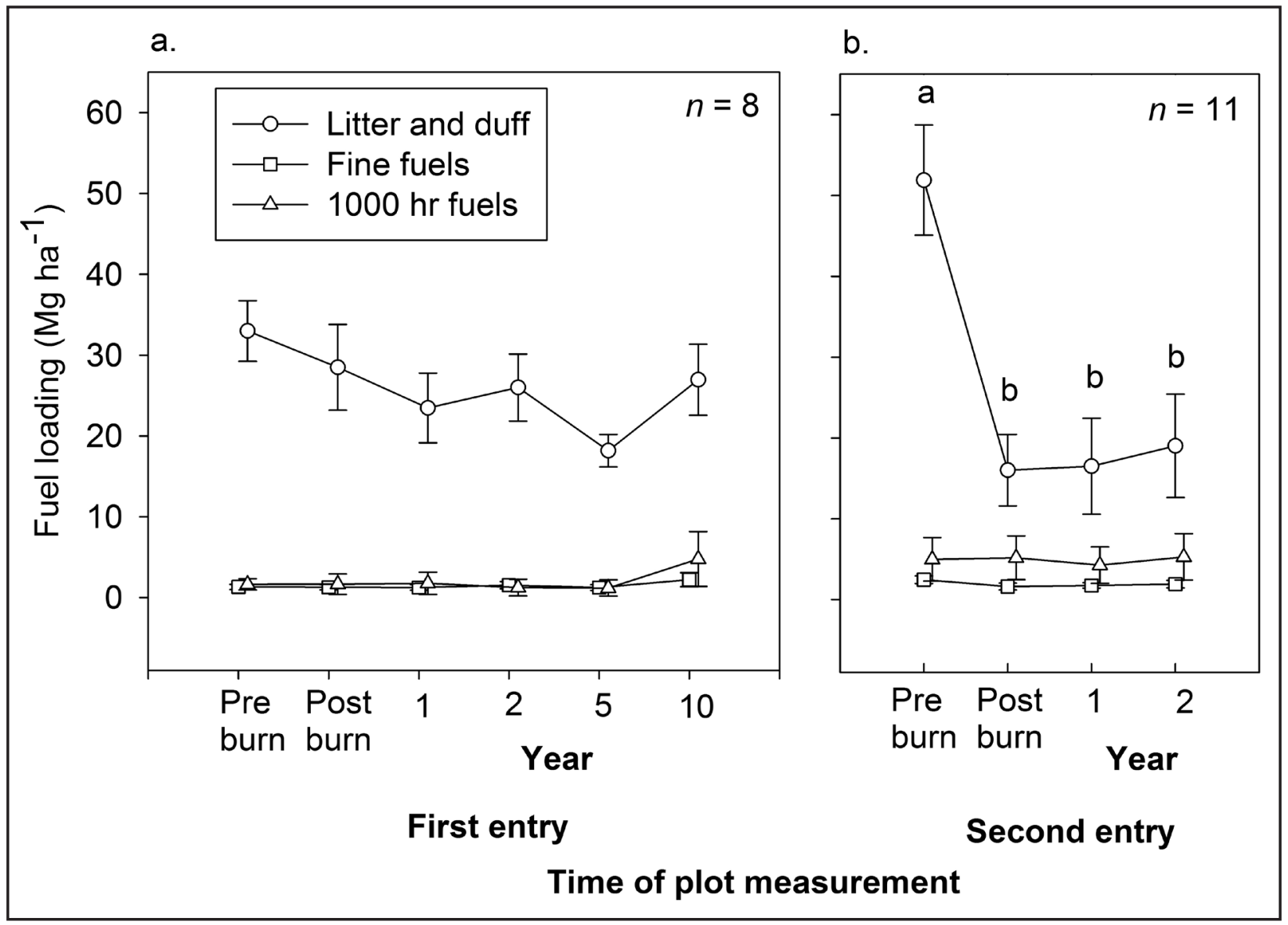

Figure 6. Fuel loading through time for (a) first entry fires and (b) second entry fires. Different letters indicate significant differences between treatment years $(\alpha \leq 0.05)$. Bars and lines represent means and standard errors. Time of plot measurement indicates when measurements occurred: Pre and post burn $=$ immediately pre or post fire; numbers indicate years post fire. Fine fuels $=1 \mathrm{hr}, 10 \mathrm{hr}$, and $100 \mathrm{hr}$ time lag fuels. Data from permanent monitoring plots located at Zion National Park, Utah, USA.

diameter distribution for both species shifted towards larger trees and a more unimodal shape (Figure 4). No change was seen in basal area for any species (Table 3). Ponderosa pine seedlings were found in the two smaller height classes $(0.01 \mathrm{~m}$ to $0.60 \mathrm{~m}) 1 \mathrm{yr}$ post fire with 151 trees ha $^{-1}$, but in year 2 were present in only the smallest height class (Figures $7 \mathrm{~b}$ and 7d).

Total understory vegetation cover decreased following the second entry fire $\left(F_{2,30}=\right.$ 4.86, $P=0.014$; Table 3$)$. This decrease was driven by changes in shrub cover, which significantly decreased by $61 \% 1 \mathrm{yr}$ post fire, a significant change $\left(F_{2,30}=3.06, P=0.050\right)$.
No differences were found in Gambel oak cover. Forb cover decreased 1 yr post fire with a recovery to pre-treatment levels by year 2 , similar to first entry fire response (not significant: $F_{2,30}=0.385, P=0.68$; Table 3 ). Perennial graminoid cover decreased in year 1 , and did not recover to pre-fire levels by year 2 (Table 3). Exotic grass species were not present after the second entry (data not shown). We found no changes in bare ground cover (Figure 5). Litter cover increased significantly by $32 \%\left(F_{2,32}=4.921, P=0.004\right)$, followed by a slight decrease in year 2 post fire $\left(F_{2,32}=4.921\right.$, $P=0.037$; Figure 5). Fuel loading significantly decreased by $54 \%$ immediately post fire 


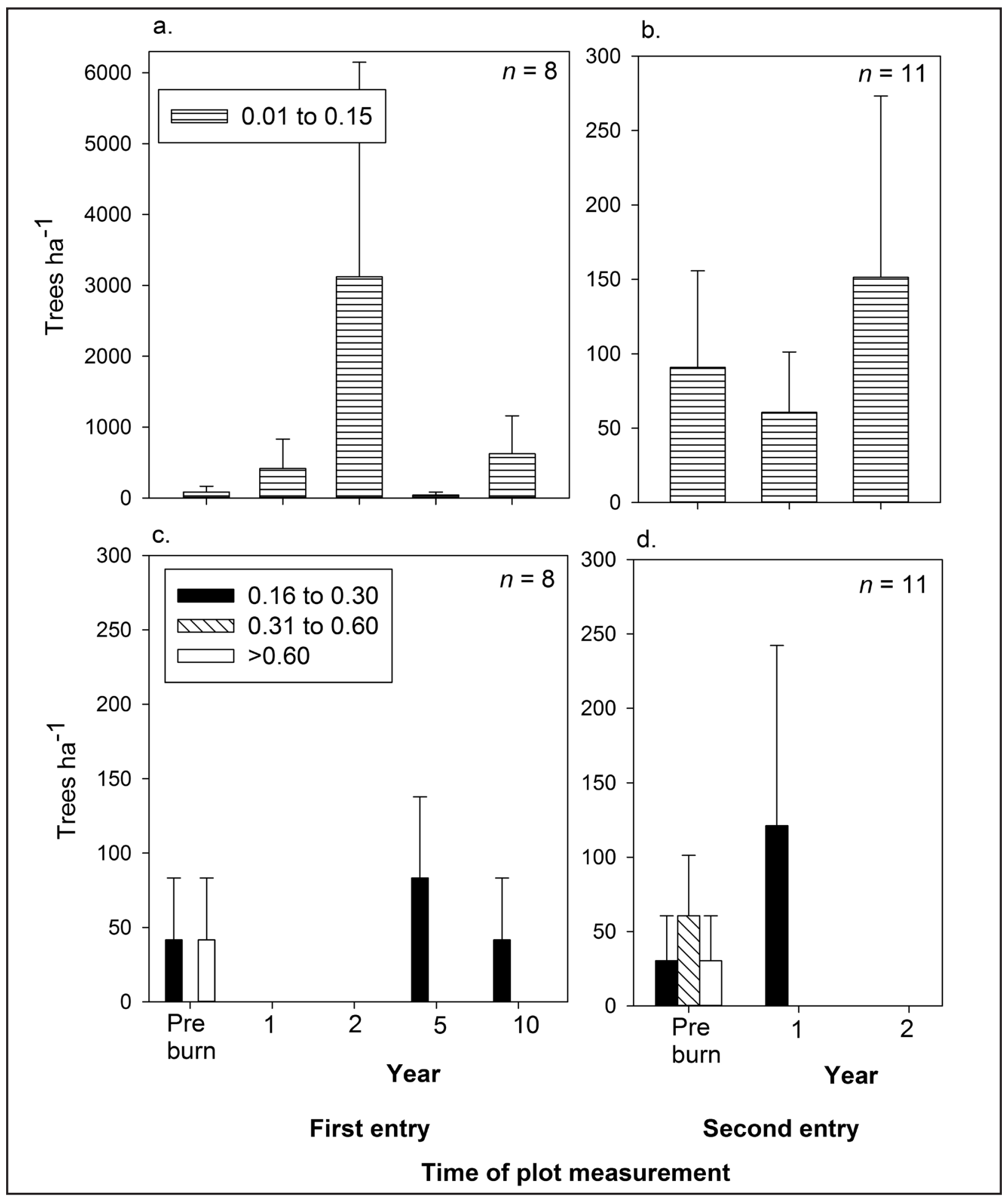

Figure 7. Ponderosa pine seedling density through time by height class: (a) first entry fire seedlings 0.01 $\mathrm{m}$ to $0.15 \mathrm{~m}$ tall, (b) second entry fire seedlings $0.01 \mathrm{~m}$ to $0.15 \mathrm{~m}$ tall, (c) first entry seedlings from $0.16 \mathrm{~m}$ to $1.0 \mathrm{~m}$ tall, and (d) second entry seedlings from $0.16 \mathrm{~m}$ to $1.0 \mathrm{~m}$ tall. Note the difference in $y$-axis scale between (a) and the others. Bars and lines represent means and SE. Time of plot measurement indicates when measurements occurred: Pre burn = immediately pre fire, numbers indicate years post fire. No significant differences were found. Data from permanent monitoring plots located at Zion National Park, Utah, USA. 
Table 3. Mean (SE) understory and overstory attributes within ponderosa pine prescribed fire burn units by time since burned for a second entry fire. All percentages represent percent cover measurements. Letters represent significant differences $(\alpha \leq 0.05)$ between treatment years using PERMANOVA; $n=11$ plots. QUGA $=$ Gambel oak, PIPO = ponderosa pine. Data from permanent monitoring plots located at Zion National Park, Utah, USA.

\begin{tabular}{lccc}
\hline & Pre fire & \multicolumn{2}{c}{ Post-fire years since fire } \\
\cline { 3 - 4 } & & $\mathbf{1}$ & $\mathbf{2}$ \\
\hline Understory cover (\%) & & \\
Shrub cover & $22.2(5.3)^{\mathrm{a}}$ & $8.7(2.8)^{\mathrm{b}}$ & $11.6(3.7)^{\mathrm{b}}$ \\
QUGA cover & $23.3(4.6)$ & $16.3(4.4)$ & $19.1(3.3)$ \\
Forb cover & $9.3(2.6)$ & $7.3(1.2)$ & $9.5(1.8)$ \\
Perennial graminoid cover & $7.6(4.4)$ & $3.6(2)$. & $3.2(2.0)$ \\
Total understory vegetation cover & $63.1(8.4)^{\mathrm{a}}$ & $34.8(5.2)^{\mathrm{b}}$ & $44.5(4.5)^{\mathrm{b}}$ \\
\hline & & & \\
Overstory and midstory & & & \\
PIPO overstory basal area $\left(\mathrm{m}^{2} \mathrm{ha}^{-1}\right)$ & $24.6(2.8)$ & $24.5(2.8)$ & $23.7(3.1)$ \\
PIPO midstory basal area $\left(\mathrm{m}^{2} \mathrm{ha}^{-1}\right)$ & $1.4(0.4)$ & $0.6(0.3)$ & $0.7(0.3)$ \\
QUGA overstory density $\left(\right.$ trees ha $\left.^{-1}\right)$ & $17.3(15.4)$ & $10.0(10.0)$ & $10.0(10.0)$ \\
QUGA midstory density $\left(\right.$ trees ha $\left.^{-1}\right)$ & $396.4(198.4)^{\mathrm{a}}$ & $20.9(11.8)^{\mathrm{b}}$ & $32.7(20.1)^{\mathrm{b}}$ \\
\hline
\end{tabular}

$\left(F_{3,40}=4.029, P=0.008\right)$ and the mass was still $48 \%$ below pre-fire levels 2 yr post fire $\left(F_{3,40}=4.029, P=0.024\right.$; Figure 6). Again, the consumption of litter and duff contributed to these changes with a significant decrease of $79 \%$ immediately post fire $\left(F_{3,40}=8.525, P<\right.$ 0.001 ; Figure 6). Fine and heavy fuels were not reduced by the second entry fire (Figure $6)$.

Power analysis indicated that, to detect significant differences in trees ha ${ }^{-1}$ with $95 \%$ confidence in second entry fires between all years (pre fire and $1 \mathrm{yr}$ and $2 \mathrm{yr}$ post fire), 4 plots would be needed (effect size $=1.45$ trees $\left.\mathrm{ha}^{-1}\right)$. Using Zion guidelines of being $80 \%$ confident of detecting differences would require only 3 plots (effect size $=1.45$ trees ha$\left.{ }^{1}\right)$. Both projected sample sizes are below the $n=11$ plots analyzed in this research.

\section{DISCUSSION}

Madany (1981) calculated that pre-Euro-American ponderosa pine tree density within Zion approximated 100 trees ha- ${ }^{-1}$. By contrast, we found that the pre-prescribed fire, contemporary stand density of overstory and midstory ponderosa pine within Zion was 302 trees ha ${ }^{-1}$, more than three times the pre-settlement density. The Zion Fire Management Plan states that ponderosa pine overstory reduction by $30 \%$ to $60 \%$ is the main objective of prescribed fire treatments in the ponderosa pine forest (USDI NPS 2005). First entry fires reduced overstory and midstory pine densities by just $10 \%$, and the second entry fires reduced the density by $24 \%$. While second entry density reductions were not statistically significant, the actual densities approximate those observed historically and are relatively close to the minimum density reduction objective of $30 \%$. Ponderosa pine basal area did not change after the first or second entry fires, indicating that primarily smaller trees were removed by the burns; this also meets the Zion objective of primarily removing trees within the $10.2 \mathrm{~cm}$ to $30.5 \mathrm{~cm}$ diameter classes.

Power analysis indicated that sample sizes were not sufficient to detect any long term changes that occurred, likely due to high spatial (i.e., among plots) variability in pre-fire conditions and post-fire response. Conversely, current sample sizes were large enough to detect short term changes following second entry fires. The lack of significant findings following first entry fire may also be due to pseu- 
doreplication of plots, which is inherent in prescribed fire analysis with multiple burn units over multiple years (van Mantgem et al. 1999), or to the overall low burn severity found in the monitoring plots (Figure 1, Table 1).

\section{Effectiveness of Prescribed Fire in Meeting Objectives}

Ponderosa pine. Although management objectives state a desired decrease in ponderosa pine densities, there has been an increasing concern throughout the West about the lack of adequate ponderosa pine regeneration (Bailey and Covington 2002). Research by Savage and Mast (2005) suggested that stand-replacing crown fires within ponderosa pine forests may contribute to delayed regeneration, depending on climate, seed source availability, and post-fire land management. Harrington (1985) suggested that, in mixed stands, Gambel oak may have an allelopathic effect that limits ponderosa pine regeneration. We found that, following prescribed fire, ponderosa pine seedling densities were highest in the smallest height class, but only about $3 \%$ of these seedlings survived. The $3 \%$ survival is lower than those reported in other ponderosa pine postfire studies, where concerns are related to an over-abundance of regeneration (Battaglia et al. 2008, Higgins et al. 2015). In order to maintain pre-settlement ponderosa pine tree densities and multiple age classes, Mast et al. (1999) found that 3.6 trees ha ${ }^{-1}$ decade $^{-1}$ was a sufficient level of recruitment for eventual overstory replacement and forest sustainability. Pearson (1950) and Schubert (1974) identified several critical factors necessary for regeneration success in ponderosa pine: time of germination, freedom from competition, and exposure of bare mineral soil. Pre settlement, these conditions were met in microsites created from frequent fire (Schubert 1974). In this study, after both first and second entry fires, litter covered more than $50 \%$ of the forest floor and bare ground was only exposed in ap- proximately $5 \%$ of the remaining areas. Given that our plots burned at low severity, moderate severity fire may provide more bare ground and a less tightly packed litter layer and, subsequently, a higher chance of germination for pine seedlings. However, fires of higher severity have the potential to increase mortality of small established seedlings. In this study, after a second entry fire, litter and duff fuel loading decreased significantly; however, seedling germination was less abundant than it was following the first entry fire, and all seedlings had disappeared by year 2. Rate of ponderosa pine germination is related to cone crop size and specific climatic conditions (Savage et al. 1996) in addition to certain microsite conditions (Schubert 1974). In this context, the high rate of mortality that we observed in the smallest seedling height class is probably not unusual (Schubert 1974), and we did find that density of established seedlings $(>0.15 \mathrm{~m}$ tall) was greater than the threshold densities required to sustain ponderosa pine populations following both first and second entry fires.

Fuel loading. The accumulation of fuels on the forest floor that has occurred in the Southwest can be attributed to natural fire exclusion and suppression (Covington and Moore 1994). A stated objective of prescribed fire treatments is to decrease this abundance of dead and down fuels, and the second entry fires in this study significantly decreased the total fuel loading. Decreases in the litter and duff layer accounted for much of the reduction and were within the range of management objectives ( $40 \%$ to $60 \%$ decrease). Total fuel mass was still high at $31 \mathrm{Mg} \mathrm{ha}^{-1}$ immediately after the second entry fire and $1000 \mathrm{hr}$ fuel loading was not reduced, thus the fuel loading objective was only partially met by second entry fires (and not met by first entry fires). Additionally, the remaining fine and heavy fuels were enough to support high severity crown fires (Fulé et al. 1997, 2001). 
Gambel oak. Overstory Gambel oak tree density, which was low prior to the study, decreased after both first and second entry fires. Large tree mortality was higher following the second entry fires and may be cause for concern in future fire entries. Large, overstory Gambel oak provides forage, habitat for wildlife, and erosion control in watersheds (Harper et al. 1985). Mast (2003) suggested that one factor that has caused a decline in larger Gambel oaks in the overall ponderosa pine landscape, but not at Zion, is firewood cutting. Abella and Fulé (2008) suggested that large Gambel oaks (>15 cm dbh) have sufficient ecological and aesthetic value to warrant protection of surviving trees through management actions. Suggested fire-related management actions to protect large Gambel oak include raking around larger stems before burning, and not burning near clumps that include larger diameter oaks or near the tree bases (Abella and Fulé 2008).

Thickets of midstory Gambel oak, however, were pervasive throughout the study area. While we predicted the decline of these trees, the mortality of most midstory Gambel oak stems likely stimulated the resprouting of many smaller oak stems in the understory (Harrington 1985). This phenomenon was observed in our understory Gambel oak cover data, which exceeded pre-fire levels by year 10 post fire. Large crown fires in a ponderosa pine overstory may follow the successional pathway leading to a Gambel oak shrub field, which would then be self-perpetuating (Bradley et al. 1992, Savage and Mast 2005). To prevent Gambel oak encroachment into open spaces where herbaceous species as well as ponderosa pine seedlings thrive, Harrington (1985) recommended burning repeatedly in mid-summer.

Understory. Historically, frequent, low intensity surface fires maintained an abundant, diverse ground cover underneath an open ponderosa pine overstory (Arnold 1950, Cooper
1960). Indeed, perennial graminoid abundance is inversely related to the density of ponderosa pine forest (Pase 1958, Covington and Moore 1994). In this study, the decrease in herbaceous cover after both first and second entry fires is inconsistent with other studies of restoration treatments in ponderosa pine forests (Covington et al. 1997, Griffis et al. 2001, Moore et al. 2006). Continuation of long term monitoring may be necessary due to the disproportionately long response time for some understory species (Moore et al. 2006, Laughlin et al. 2008). However, given that there was no change in ponderosa pine overstory density following either first or second entry fires, it follows that herbaceous species would not increase without a corresponding decrease in overstory density. We found that woody shrub cover decreased along with Gambel oak cover, but only Gambel oak cover recovered through time. It is well documented that small stem Gambel oaks recover rapidly to pre-fire levels (Harrington 1985, Abella and Fulé 2008). However, the recommendation of repeated burning to maintain small stem oaks at low levels (Harrington 1985) could have implications for the herbaceous understory that requires a longer post-fire response time ( $\geq 10 \mathrm{yr}$ ).

\section{Management and Monitoring Implications}

Sackett et al. (1994) suggest that prescribed fire alone can be used to thin overly dense ponderosa pine stands; however, repeated treatments must be used to replicate the pre-settlement frequent fire regime. Prescribed fire has been the most frequent treatment option chosen by managers at Zion to reduce overstory density (USDI NPS 2005). However, increased forest density and fuel accumulation due to a century of fire exclusion mean that objectives related to forest structure and fuel loads may not be quickly met through one or even two low intensity prescribed burns (Stephens et al. 2009). In ponderosa 
pine forests at Zion, stand level fire history reconstructions estimated mean fire return intervals of 4 yr to $8 \mathrm{yr}$ (Madany and West 1983), indicating that forests are highly departed from the historic range of variation in fire frequency following approximately $120 \mathrm{yr}$ of fire exclusion (Fire Regime Condition Class 3; Barrett et al. 2010). This highly departed condition is typical of dry, low elevation ponderosa pine forests throughout the western US (USDI GS 2013). Multiple prescribed fires at short intervals (less than the current mean of 8.9 yr between prescribed fires) or moderate intensity fires may be necessary to restore conditions that can then be maintained by occasional low intensity fires that are more typical of the historical fire regime.

Our results suggest that neither first nor second entry fires met all management objectives, but second entry fires were more effective than first entry fires, which failed to meet any objectives. Continuation of fires in these areas may enhance the understory by continuing to reduce dead and down fuels, expose bare mineral soil, and promote herbaceous growth. We recommend the addition of a management objective related to increasing native herbaceous cover as a diverse understory promotes low intensity surface fires, provides forage for wildlife, and contributes to biodiversity (Moore et al. 2006, Laughlin et al. 2008). Results from a first entry prescribed fire often do not meet fuel reduction objectives due to the long history of fire exclusion and the lack of ladder fuel removal (Cooper 1960, Stephens et al. 2009). The needle cast post fire leads to a higher fuel loading that a second entry fire will remove with less postfire needle cast. We recommend the use of multiple fire entries or higher intensity fire to more effectively achieve a broader array of objectives. However, these recommendations are based on a small set of pseudoreplicated plots and should not be the sole determinant of whether objectives have been met or if the original objectives were valid. For example, Zion has an objective of maintaining large
$(>61 \mathrm{~cm} \mathrm{dbh})$ ponderosa pine in the landscape. This objective could not be evaluated because too few large trees were present on the monitoring plots. Fire managers should use results from monitoring along with their expertise in prescribed fire treatment prescriptions, intensity, season, interval, and implementation, plus any limitations (e.g., policy), to adjust their prescribed burning program to better meet objectives.

High quality, long term fire effects data are an essential component of adaptive management on public lands. This data enables managers to evaluate the achievement of prescribed burn objectives and adapt fire management activities according to ecosystem response. Indeed, this information may become even more crucial as climate changes in the coming decades and managers are forced to move beyond the safety of historic reference conditions (Stephenson 2014). Unfortunately, we found that, at Zion, low sample sizes limit the range of questions that can be addressed with fire effects data, and strength of any conclusions drawn. The NPS-wide fire monitoring handbook establishes protocols for adequate sample sizes, but limited resources at Zion impeded managers from strictly adhering to these protocols. Limited sample sizes and inconsistent data archiving are likely a reality at many parks, perhaps with the exception of the largest parks that maintain extensive fire management and monitoring programs (Fulé and Laughlin 2007, van Mantgem et al. 2013). Data at Zion were suitable for identifying short term trends in responses to the application of prescribed fire in its most general sense (i.e., fire vs. no fire rather than testing specific prescribed fire approaches related to seasonality, severity, frequency, and ignition pattern) but failed in providing a minimum level of certainty on whether long term management objectives were achieved. The identification of these short term, non-significant trends may be adequate to justify continued burning and inform some management decisions. However, managers at Zion and beyond are facing more 
complicated management decisions as they refine their use of fire (Ryan et al. 2013). Questions pertaining to the use of higher intensity fire, fire seasonality, and the effects of climate change would benefit from large sample sizes suited to more robust statistical analysis.

The addition of new permanent plots is the most direct solution to improve the utility of fire effects data. This approach would require a significant increase in commitment of resources, more than tripling the current number of monitoring plots to adequately assess long term fire effects at Zion. Yet money invested in effective restoration might be well spent, compared to money spent on reactive fire suppression efforts (North et al. 2015). In the absence of funds to establish additional plots, monitors could take smaller steps that would increase the value of ongoing data collection. For example, monitors should ensure that data on fire weather and fire behavior are collected in detail on the day of the fire, then digitized and made readily available for analysis within the fire effects monitoring software. At a minimum, FMH databases should contain explicit information regarding fire date, National Fire Danger Rating System (NFDRS) fuel model, and NFDRS indices. Hard copies of data on individual fire behavior and fire weather are supposed to be on file at Zion, but we were unable to locate this information. Accurate and readily available data on fire weather and fire behavior will be essential if managers are interested in assessing the outcomes of moderate severity fires. Sample sizes and the strength of conclusions can be increased by combining data across park units (e.g., van Mantgem et al. 2013). We originally intended to include similar FMH data from ponderosa pine plots at Bryce Canyon National Park, but found too many irregularities in the data to pool them. Therefore, it is essential that monitoring data be collected in a consistent manner that facilitates analysis across park unit boundaries. A network of regional fire science consortia have recently been established with the goal of identifying and disseminating information between scientists, practitioners, and managers (Kocher et al. 2012, www.firescience.gov/ JFSP_exchanges.cfm). This network places further importance on the collection of high quality data that can be regularly shared across administrative boundaries. Finally, data from prescribed fire effects plots could be supplemented with information from managed lightning ignitions, either through remotely sensed images collected pre and post fire, or through comparison of adjacent burned and unburned plots.

The federal fire effects monitoring program is an important and necessary component of resource management in the national parks. However, the future of the fire effects monitoring program is uncertain at Zion and elsewhere due to budget and staffing cuts (Abendroth et al. 2014). We hope that, in the long term, leadership within the NPS will recognize the importance of this program in supporting well informed adaptive management.

\section{ACKNOWLEDGEMENTS}

This research was supported by the Intermountain Region of the National Park Service and the Colorado Plateau Ecosystems Study Unit Award No. NAU-320 (to K. Waring). We thank the managers at Zion who contributed their time and insight to this project, particularly C. Decker, K. Legg, B. Woffinden, and T. Rohrer. We extend a special thanks to all the fire effects monitors at Zion, without whom this research would not have been possible. We appreciate comments provided by D. Auty, P. Fulé, M. Miller, and two anonymous reviewers to help us improve this manuscript. 


\section{LITERATURE CITED}

Abella, S.R., and P.Z. Fulé. 2008. Fire effects on Gambel oak in southwestern ponderosa pine oak forests. USDA Forest Service Research Note RMRS-RN-34, Rocky Mountain Research Station, Fort Collins, Colorado, USA.

Abendroth, D., W. Bunn, S. Leis, R. Smith, D. Swanson, and K. Walsh. 2014. Discussion topic: essential fire ecology. RxEffects 1(13): 1-3.

Allen, C.D., A.K. Macalady, H. Chenchouni, D. Bachelet, N. McDowell, M. Vennetier, T. Kitzberger, A. Rigling, D.D. Breshears, E.H. Hogg, P. Gonzalez, R. Fensham, Z. Zhang, J. Castro, N. Demidova, J.H. Lim, G. Allard, S.W. Running, A. Semerci, and N. Cobb. 2010. A global overview of drought and heat-induced tree mortality reveals emerging climate change risks for forests. Forest Ecology and Management 259: 660-684. doi: 10.1016/j.foreco. 2009.09.001

Allen, C.D., M.O. Savage, K.F. Suckling, T.W. Swetnam, T. Schulke, P.B. Stacey, P. Morgan, M. Hoffman, and J.T. Klingel. 2002. Ecological restoration of southwestern ponderosa pine ecosystems: a broad perspective. Ecological Applications 12: 1418-1433. doi: 10.1890/1051-0761(2002)012[1418:EROSPP]2.0.CO;2

Anderson, M.J. 2001. A new method for non-parametric multivariate analysis of variance. Austral Ecology 26: 32-46.

Arno, S.E., M.G. Harrington, C.E. Fielder, and C.E. Carlson. 1995. Restoring fire-dependent ponderosa pine forests in western Montana. Restoration and Management Notes 13: 32-36.

Arnold, J.F. 1950. Changes in ponderosa pine bunchgrass ranges in northern Arizona resulting from pine regeneration and grazing. Journal of Forestry 48: 118-126.

Bailey, J.D., and W.W. Covington. 2002. Evaluating ponderosa pine regeneration rates following ecological restoration treatments in northern Arizona, USA. Forest Ecology and Management 155: 271-278. doi: 10.1016/S0378-1127(01)00564-3

Barrett, J.W., P.M. McDonald, F. Ronco Jr., and R.A. Ryker. 1980. Interior ponderosa pine. Pages 114-115 in: F.H. Eyre, editor. Forest cover types of the United States and Canada. USDA Forest Service, Washington, D.C., USA.

Barrett, S., D. Havlina, J. Jones, W. Hann, C. Frame, D. Hamilton, K. Schon, T. Demeo, L. Hutter, and J. Menakis. 2010. Interagency fire regime condition class guidebook. Version 3.0. $<$ https://www.frames.gov/frcc >. Accessed 28 January 2016.

Battaglia, M.A., F.W. Smith, and W.D. Shepperd. 2008. Can prescribed fire be used to maintain fuel treatment effectiveness over time in Black Hills ponderosa pine forests? Forest Ecology and Management 256: 2029-2038. doi: 10.1016/j.foreco.2008.07.026

Bradley, A.F., N.V. Noste, and W.C. Fischer. 1992. Fire ecology of forests and woodlands in Utah. USDA Forest Service General Technical Report INT-287, Intermountain Research Station, Ogden, Utah, USA.

Brown, J.K. 1974. Handbook for inventorying downed material. USDA Forest Service General Technical Report INT-16, Intermountain Forest and Range Experiment Station, Ogden, Utah, USA.

Cooper, C.F. 1960. Changes in vegetation, structure, and growth of southwestern pine forests since white settlement. Ecological Monographs 30: 130-164. doi: 10.2307/1948549

Covington, W.W., P.Z. Fulé, M.M. Moore, S.C. Hart, T.E. Kolb, J.N. Mast, S.S. Sackett, and M.R. Wagner. 1997. Restoring ecosystem health in ponderosa pine forests of the Southwest. Journal of Forestry 95: 23-29. 
Covington, W.W., and M.M. Moore. 1994. Southwestern ponderosa forest structure and resource conditions: changes since Euro-American settlement. Journal of Forestry 92: 39-47.

Fulé, P.Z., W.W. Covington, and M.M. Moore. 1997. Determining reference conditions for ecosystem management of southwestern ponderosa pine forests. Ecological Applications 7: 895908. doi: 10.1890/1051-0761(1997)007[0895:DRCFEM]2.0.CO;2

Fulé, P.Z., J.E. Crouse, A.E. Cocke, M.M. Moore, and W.W. Covington. 2004. Changes in canopy fuels and potential fire behavior 1880-2040: Grand Canyon, Arizona. Ecological Modelling 175: 231-248. doi: 10.1016/j.ecolmodel.2003.10.023

Fulé, P.Z., J.E. Crouse, J.P. Roccaforte, and E.L. Kalies. 2012. Do thinning and/or burning treatments in western USA ponderosa or Jeffrey pine-dominated forests help restore natural fire behavior? Forest Ecology and Management 269: 68-81. doi: 10.1016/j.foreco.2011.12.025

Fulé, P.Z., and D.C. Laughlin. 2007. Wildland fire effects on forest structure over an altitudinal gradient, Grand Canyon National Park, USA. Journal of Applied Ecology 44: 136-146. doi: 10.1111/j.1365-2664.2006.01254.x

Fulé, P.Z., A.E.M. Waltz, W.W. Covington, and T.A. Heinlein. 2001. Measuring forest restoration effectiveness in reducing hazardous fuels. Journal of Forestry 99: 24-29.

Griffis, K.L., J.A. Crawford, M.R. Wagner, and W.H. Moir. 2001. Understory response to management treatments in northern Arizona ponderosa pine forests. Forest Ecology and Management 146: 239-245. doi: 10.1016/S0378-1127(00)00461-8

Harper, K.T. 1993. Zion National Park vegetation: summary report. Zion National Park, Springdale, Utah, USA.

Harper, K.T., F.J. Wagstaff, and L.M. Kunzler. 1985. Biology and management of Gambel oak vegetation type: a literature review. USDA Forest Service General Technical Report INT179, Intermountain Forest and Range Experiment Station, Ogden, Utah, USA.

Harrington, M.G. 1985. The effects of spring, summer, and fall burning on Gambel oak in a southwestern ponderosa pine stand. Forest Science 31: 156-163.

Harrington, M.G., and S.S. Sackett. 1990. Using fire as a management tool in southwestern ponderosa pine. Pages 122-133 in: J.S. Krammes, technical coordinator. Effects of fire in management of southwestern natural resources. USDA Forest Service General Technical Report RM-191, Rocky Mountain Forest and Range Experiment Station, Fort Collins, Colorado, USA.

Harrington, M.G., and S.S. Sackett. 1992. Past and present fire influences on southwestern ponderosa pine old growth. Pages 44-50 in: M.R. Kaufmann, W.H. Moir, and R.L. Bassett, technical coordinators. Old-growth forests in the Southwest and Rocky Mountain regions: proceedings of a symposium. USDA Forest Service General Technical Report RM-213, Rocky Mountain Forest and Range Experiment Station, Fort Collins, Colorado, USA.

Higgins, A.M., K.M. Waring, and A.E. Thode. 2015. The effects of burn entry and burn severity on ponderosa pine and mixed conifer forests in Grand Canyon National Park. International Journal of Wildland Fire 24: 495-506. doi: 10.1071/WF13111

Kocher, S.D., E. Toman, S.F. Trainor, V. Wright, J.S. Briggs, C.P. Goebel, E.M. MontBlanc, A. Oxarart, D.L. Peppin, T.A. Steelman, A. Thode, and T.A. Waldrop. 2012. How can we span the boundaries between wildland fire science and management in the United States? Journal of Forestry 110: 421-428. doi: 10.5849/jof.11-085

Laughlin, D.C., J.D. Bakker, M.L. Daniels, M.M. Moore, C.A. Casey, and J.D. Springer. 2008. Restoring plant species diversity and community composition in a ponderosa pine-bunchgrass ecosystem. Plant Ecology 197: 139-151. doi: 10.1007/s11258-007-9367-9 
Leopold, A.S., S.A. Cain, C.M. Cottam, I.N. Gabrielson, and T.C. Kimball. 1963. Wildlife management in the national parks. US Department of the Interior, Washington, D.C., USA.

Lutes, D.C., N.C. Benson, M.B. Keifer, J.F. Caratti, and S.A. Streetman. 2009. FFI: a software tool for ecological monitoring. International Journal of Wildland Fire 18: 310-314. doi: 10.1071/WF08083

Madany, M.H. 1981. Land use-fire regime interactions with vegetation structure of several montane forest areas of Zion National Park. Thesis, Utah State University, Logan, USA.

Madany, M.H., and N.E. West. 1983. Livestock grazing-fire regime interactions within montane forests of Zion National Park, Utah. Ecology 64: 661-667. doi: 10.2307/1937186

Mast, J.N. 2003. Tree response to restoration in ponderosa pine forests of the southwest. Pages 215-232 in: P. Friederici, editor. Ecological restoration of southwestern ponderosa pine forests. Island Press, Covelo, California, USA.

Mast, J.N., P.Z. Fulé, M.M. Moore, W.W. Covington, and A.E.M. Waltz. 1999. Restoration of presettlement age structure of an Arizona ponderosa pine forest. Ecological Applications 9: 228-239. doi: 10.1890/1051-0761(1999)009[0228:ROPASO]2.0.CO;2

McCune, B., and M.J. Mefford. 2006. PC-ORD. Multivariate analysis of ecological data. Version 5. MjM Software, Gleneden Beach, Oregon, USA.

Moore, M.M., C.A. Casey, J.D. Bakker, J.D. Springer, P.Z. Fulé, W.W. Covington, and D.C. Laughlin. 2006. Herbaceous vegetation responses (1992-2004) to restoration treatments in a ponderosa pine forest. Rangeland Ecology and Management 59: 135-144. doi: 10.2111/ 05-051R2.1

Mortensen, V.L., J.A. Carley, G.C. Crandall, K.M. Donaldson Jr., and G. Leishman. 1977. Soil survey of Washington County area, Utah. USDA Soil Conservation Service, Washington, D.C., USA.

North, M.P., S.L. Stephens, B.M. Collins, J.K. Agee, G. Aplet, J.F. Franklin, and P.Z. Fulé. 2015. Reform forest fire management. Science 349: 1280-1281. doi: 10.1126/science.aab2356

Pase, C.P. 1958. Herbage production and composition under immature ponderosa pine stands in the Black Hills. Journal of Range Management 11: 238-243. doi: 10.2307/3894526

Pearson, G.A. 1950. Management of ponderosa pine in the Southwest. United States Forest Service Agricultural Monograph Number 6, Washington, D.C., USA.

R Core Development Team. 2015. R: a language and environment for statistical computing. R Foundation for Statistical Computing, Vienna, Austria. [Available online at: http://www.R-project.org]

Ryan, K.C., E.E. Knapp, and J.M. Varner. 2013. Prescribed fire in North American forests and woodlands: history, current practice, and challenges. Frontiers in Ecology and the Environment 11: e15-e24. doi: 10.1890/120329

Sackett, S.S., S. Haase, and M.G. Harrington. 1994. Restoration of southwestern ponderosa pine forests with fire. Pages 115-121 in: W.W. Covington and L.F. DeBano, technical coordinators. Sustainable ecological systems: implementing an ecological approach to land management. USDA Forest Service General Technical Report RM-247, Rocky Mountain Forest and Range Experiment Station, Fort Collins, Colorado, USA.

Savage, M., P.M. Brown, and J. Feddema. 1996. The role of climate in a pine forest regeneration pulse in the southwestern United States. Ecoscience 3: 310-318.

Savage, M., and J.N. Mast. 2005. How resilient are southwestern ponderosa pine forests after crown fires? Canadian Journal of Forest Research 35: 967-977. doi: 10.1139/x05-028 
Schubert, G.H. 1974. Silviculture of southwestern ponderosa pine: the status of our knowledge. USDA Forest Service Research Paper RM-123, Rocky Mountain Research Station, Fort Collins, Colorado, USA.

Smith, D.M., B.C. Larson, M.J. Kelty, and P.M.S. Ashton. 1997. The practice of silviculture: applied forest ecology. John Wiley \& Sons, New York, New York, USA.

Stephens, S.L., J.J. Moghaddas, C. Edminster, C.E. Fiedler, S. Haase, M. Harrington, J.E. Keeley, E.E. Knapp, J.D. McIver, K. Metlen, C.N. Skinner, and A. Youngblood. 2009. Fire treatment effects on vegetation structure, fuels, and potential fire severity in western US forests. Ecological Applications 19: 305-320. doi: 10.1890/07-1755.1

Stephenson, N.L. 2014. Making the transition to the third era of natural resources management. The George Wright Forum: The GWS Journal of Parks, Protected Areas \& Cultural Sites 31: $227-235$.

USDI GS [US Department of the Interior Geological Survey]. 2013. LANDFIRE: LANDFIRE Vegetation Condition Class Layer. <http://landfire.cr.usgs.gov/viewer/>. Accessed 28 January 2016.

USDI NPS [US Department of the Interior National Park Service]. 1985. Fire Management Action Plan. USDI National Park Service, Zion National Park, Springdale, Utah, USA.

USDI NPS [US Department of the Interior National Park Service]. 1991. Western Region fire monitoring handbook. Western Region Prescribed and Natural Fire Monitoring Task Force. USDI National Park Service, San Francisco, California, USA.

USDI NPS [US Department of the Interior National Park Service]. 2003. Fire monitoring handbook. Fire Management Program Center, National Interagency Fire Center, Boise, Idaho, USA. [Available online: http://www.nps.gov/fire/wildland-fire/resources/documents/fire-effects-monitoring-handbook.pdf]

USDI NPS [US Department of the Interior National Park Service]. 2005. Wildland and prescribed fire monitoring plan. Zion National Park, Springdale, Utah, USA.

USDI NPS [US Department of the Interior National Park Service]. 2008a. Wildland fire management guideline (DO-18). National Interagency Fire Center, Boise, Idaho, USA.

USDI NPS [US Department of the Interior National Park Service]. 2008b. Reference manual 18: wildland fire management. National Interagency Fire Center, Boise, Idaho, USA.

van Mantgem, P., M. Schwartz, and M.B. Keifer. 1999. Monitoring fire effects for managed burns and wildfires: coming to terms with pseudoreplication. Natural Areas Journal 21: 266273.

van Mantgem, P.J., J.C.B. Nesmith, M. Keifer, E.E. Knapp, A. Flint, and L. Flint. 2013. Climatic stress increases forest fire severity across the western United States. Ecology Letters 16: 1151-1156. doi: 10.1111/ele.12151

Williams A.P., C.D. Allen, A.K. Macalady, D. Griffin, C.A. Woodhouse, D.M. Meko, T.W. Swetnam, S.A. Rauscher, R. Seager, H.D. Grissino-Mayer, J.S. Dean, E.R. Cook, C. Gangodagamage, M. Cai, N.G. McDowell. 2012. Temperature as a potent driver of regional forest drought stress and tree mortality. Nature Climate Change 3: 292-297. doi: 10.1038/nclimate1693 
Appendix A. Example prescribed burn unit details for a fall and a spring burn at Zion National Park, Utah, USA. Data, where available, were extracted from prescribed fire burn reports.

\begin{tabular}{|c|c|c|}
\hline $\begin{array}{r}\text { Burn unit: } \\
\text { Size: } \\
\text { Dates: } \\
\text { Ignition pattern: }\end{array}$ & $\begin{array}{c}\text { East Mesa } \\
202 \text { ha } \\
1 \text { May to } 3 \text { May } 2008 \\
\text { Exterior blacklining with } \\
\text { interior aerial ignitions }\end{array}$ & $\begin{array}{c}\text { Three Finger Mesa } \\
265 \text { ha } \\
22 \text { Oct to } 29 \text { Oct } 2008 \\
\text { Exterior blacklining with } \\
\text { interior aerial ignitions }\end{array}$ \\
\hline \multicolumn{3}{|l|}{ Weather conditions } \\
\hline Average $6 \mathrm{~m}$ wind speed $\left(\mathrm{km} \mathrm{hr}^{-1}\right.$, desired $)$ & 13 to 16 & 16 \\
\hline $\begin{array}{l}\text { Dry bulb temperature } \\
\text { Average maximum }\left({ }^{\circ} \mathrm{C}\right)\end{array}$ & 13 & 17 \\
\hline \multicolumn{3}{|l|}{ Relative humidity } \\
\hline $\begin{array}{l}\text { Flame length } \\
\text { Average minimum }(\mathrm{cm}) \\
\text { Average maximum }(\mathrm{cm})\end{array}$ & $\begin{array}{l}14 \\
55\end{array}$ & \\
\hline \multicolumn{3}{|l|}{ Fuel conditions (desired) } \\
\hline $1 \mathrm{hr}$ fuel moisture (\%) & 6 & 6 \\
\hline $10 \mathrm{hr}$ fuel moisture $(\%)$ & 6 & 6 \\
\hline $100 \mathrm{hr}$ fuel moisture $(\%)$ & 10 & 10 \\
\hline Woody live fuel moisture (\%) & 70 to 90 & 70 to 90 \\
\hline Herbaceous live & Dormant or transition & Dormant or transition \\
\hline
\end{tabular}

